\title{
Retraction: MyoD-dependent regulation of NF-KB activity couples cell-cycle withdrawal to myogenic differentiation
}

\author{
Maura H Parker ${ }^{1,2,3}$, Julia von Maltzahnn ${ }^{2}$, Nadine Bakkar ${ }^{6}$, Ban Al-Joubori ${ }^{2}$, Jeff Ishibashi ${ }^{2}$, Denis Guttridge ${ }^{4}$ \\ and Michael A Rudnicki ${ }^{*}$
}

\section{Retraction notice}

The authors would like to retract the article "MyoDdependent regulation of NF- $\mathrm{kB}$ activity couples cell-cycle withdrawal to myogenic differentiation" [1]. After the article was published, the first author revealed that the tubulin blots in Figures 1A, 3E, and 4A are from unrelated samples. The lead author and co-authors apologise to the readers, reviewers and editors for publishing this erroneous data.

\footnotetext{
Author details

${ }^{1}$ Faculty of Health Sciences Graduate Programme, McMaster University, Hamilton, ON, Canada. ${ }^{2}$ Ottawa Hospital Research Institute, Molecular Medicine Program, Ottawa, ON, Canada. ${ }^{3}$ Current address: Fred Hutchinson Cancer Research Center, Clinical Research Division, Seattle, WA, USA. ${ }^{4}$ The Ohio State University College of Medicine, Columbus, OH, USA. ${ }^{5}$ Ottawa Hospital Research Institute, 501 Smyth Rd, Ottawa, ON K1H 8L6, Canada. ${ }^{6}$ Greg W Fulton ALS and Neuromuscular Research Center, Barrow

Neurological Institute, Phoenix, AZ, USA.
}

Received: 17 June 2013 Accepted: 17 June 2013

Published: 18 July 2013

\section{References}

1. Parker MH, von Maltzahn J, Bakkar N, Al-Joubori B, Ishibashi J, Guttridge D, Rudnicki MA: MyoD-dependent regulation of NF-kB activity couples cell-cycle withdrawal to myogenic differentiation. Skeletal Muscle 2012, 2:6.

Submit your next manuscript to BioMed Central and take full advantage of:

- Convenient online submission

- Thorough peer review

- No space constraints or color figure charges

- Immediate publication on acceptance

- Inclusion in PubMed, CAS, Scopus and Google Scholar

- Research which is freely available for redistribution

\section{Biomed Central}

